\title{
Estado de Malestar ${ }^{1}$
}

\section{State of discomfort}

\author{
María Gracia Quiroga y Raúl Gustavo Ferreyra ${ }^{3}$ \\ Universidad de Buenos Aires - Argentina
}

Revista Derechos en Acción ISSN 2525-1678/ e-ISSN 2525-1686

Año 5/N 15, Otoño 2020 (21 marzo a 21 junio), 330-335

DOI: https://doi.org/10.24215/25251678e402

"El agua no ofrece resistencia. El agua fluye. Cuando sumerges la mano en el agua, lo único que notas es una caricia. El agua no es un muro sólido, no te puede detener. Pero el agua siempre va a donde quiere, y al final nada puede oponerse a ella. El agua es paciente. Las gotas de agua pueden erosionar la piedra. No lo olvides, hija mía. Recuerda que eres mitad agua. Si no puedes atravesar un obstáculo, rodéalo.

Es lo que hace el agua".

Margaret ATwood, Penélope y las doce criadas

Hay un virus que recorre el mundo. No reconoce clases ni estratos sociales. Tampoco es un fantasma. En verdad, se trata de un "malestar" real, concreto, que ataca por igual a todos los seres humanos. El virus no discrimina; sí los seres humanos entre ellos.

Hace noventa años, en un estudio significativo por su riqueza para la lectura transdisciplinaria, Sigmund Freud sostuvo que el sufrimiento amenaza a los humanos por tres frentes: desde el propio cuerpo, desde el mundo exterior o natural y,

\footnotetext{
1 La autora y el autor agradecen los valiosos comentarios del Prof. Dr. Raúl Serroni-Copello.

2 Licenciada en Psicología (Universidad del Salvador). (ORCID 0000-0001-5685-840X).

3 Doctor en Derecho (Universidad de Buenos Aires) (ORCID 0000-0001-5089-8136).
} 
por fin, desde las relaciones con otros seres humanos ${ }^{4}$. Entre las líneas sin escribir, todavía, el mal del "coronavirus" carece de vacuna, pero ha pandemizado a la humanidad entera. Sin que sepamos el origen del origen, porque siempre todo ha de tener un comienzo, aunque haya sido la consecuencia de una interrupción breve o extensa.

Con los conocimientos científicos y tecnológicos disponibles, no se alcanza a controlar y curar la enfermedad desatada por el virus. Mientras no se encuentre la sanación efectiva e inmediata, lamentablemente, se mantendrían las proyecciones sobre la enfermedad y tasas de morbilidad que provoca el virus diseminado y en escala global; deseamos decir: a todos los sitios del mundo.

Para contener parcialmente el malestar ocasionado, se ha ideado y puesto en funcionamiento un modelo que en la Argentina, por ejemplo, recibe el nombre de "aislamiento social, preventivo y obligatorio" (ASPO). Con tal herramienta sanitaria se intenta que el contagio de los individuos no alcance niveles calamitosos que desborden los propios recursos del sistema de salud. Una gran paradoja. El 2020 se iluminaba como el momento en el que la mayor cantidad de seres humanos dispondrían de la mayor capacidad de traslado en toda la historia, al menos en los últimos 250.000 años. No se cumplirá el pronóstico, porque se ha hecho necesario "aislar" al ser humano, preventiva y transitoriamente, de la comunión con sus semejantes.

Así, pues, la subjetividad de los miles de millones de individuos atraviesa una fase singular, jamás acontecida. Ahora es pronto para evaluar tan siquiera los datos de este encierro global de los individuos que integran las comunidades más diversas en los espacios más disímiles. Sin embargo, hay algo que sabemos: ignoramos por completo el impacto sobre la subjetividad que provocará el ASPO, en especial, sobre la estructura sistémicofamiliar, la célula fundamental del tejido social.

4 FreUd, Sigmund (2010). El malestar en la cultura, Alianza, Madrid, [1930], p. 67. 
También se ha producido otro episodio inédito. La ciudadanía nace y se desarrolla con la presencia de otros seres humanos, con quienes se ha de acordar un "método" para producir una regla que constituya el fundamento para ordenar las existencias de una comunidad determinada. Un "método" que oriente la elaboración y el cambio de patrones generales para "guía de las acciones" que deben o pueden ser realizadas y su consecuente evaluación. El malestar que ocasionan el virus y el aislamiento hace que el ejercicio y la tutela de la ciudadanía, precisamente, se desarrollen sin la realización cotidiana de derechos de libertad básicos; una circunstancia inimaginable, irrepresentable, durísima para la salud mental de todo individuo y la consecuente legitimación del orden jurídico constituyente del Estado en el que desarrolla su ciudadanía. Que no nos quede otro camino para proteger la vida termina constituyendo otro encierro más.

Pareciera que la humanidad ha comprendido la necesidad de compartir valores elementales respecto de cómo no dañarse, cómo cuidarse y cómo desarrollarse; incluso, si esa circunstancia amerita un nuevo campo semántico (volvemos a repetir, "transitorio") para comprender el ejercicio de la ciudadanía plural. De manera constante hay que realizar un escrutinio riguroso de los derechos fundamentales; por ahora, no han sido jaqueados por el "ASPO".

En el seno de todo Estado constitucional existe la pulsión del Estado policial; por eso, el escrutinio riguroso de las medidas transitorias adoptadas por un poder concentrado es un antídoto, nunca suficiente, para las tentaciones autocráticas. El "ASPO" significa la cuarentena, "limitada" y "de excepción" de muchos derechos fundamentales, jamás la "suspensión". No distinguir que se trata, por ahora, de una limitación y no de una suspensión en Derecho constituiría el mismo error que no distinguir, en psicología, el bienestar del malestar.

El encierro obligatorio en las casas genera y generará en cada una de las individualidades diferentes comprensiones respecto del tiempo subjetivo y del tiempo cronológico. Actualmente 
existe un solo cuidado prudente: quedarnos en nuestras casas; al tratarse de una situación intempestiva, conmovedora y obligatoria, la vida anímica de cada uno de nosotros/as tendrá diferentes reacciones por el mero hecho de haber escapado a la desgracia. El encierro al romper las rutinas cotidianas, aquellas que se corresponden con las estructuras cronológicas, deja nadando al individuo en su propio tiempo subjetivo e interno.

Las medidas preventivas adoptadas por los gobiernos de los diferentes países y el distanciamiento de los individuos del clan comunitario alientan situaciones de incertidumbre y frustración, que deben ser abordados de manera inmediata con nuevas instancias de tratamiento para la salud mental. Esa falta de certeza y esa frustración temida, sin dudas, anticipa o desata nuevos estados de miedo, angustia y amenaza entre los seres humanos. Dentro de este panorama, resulta clave cuidarnos del virus, pero también debe decirse con voz propia que la salud mental constituye un capítulo decisivo del derecho a la salud de toda persona.

El virus globalizado, como malestar en la salud de la humanidad, quizá tenga espacios beneficiosos. Uno de ellos se abre respecto del enjuiciamiento de los sistemas de salud, su cobertura, su extensión, sus eminentes o sus lamentables estructuras. E interpela sobre la posibilidad de repensar los sistemas de salud. El malestar desenvuelto por este virus global no se encontraba en los libros de Medicina, Psicología o Derecho; simplemente han existido algunos hallazgos o menciones anticipatorias. Por su forma de presentación y exteriorización, el virus encierra un mal radical y globalizado.

Sin embargo, las respuestas de las políticas públicas emergentes para su contención, hasta ahora, han sido estaduales. Cada Estado propone, según su mejor y leal saber y entender, una solución tal como el virus le ha sido impuesto. Aquí no pasaremos revista a las soluciones alemana, española, italiana, estadounidense, china, coreana, argentina, colombiana, brasileña, chilena, ecuatoriana ni mexicana. Increíblemente, aunque 
el virus muta, también las respuestas estatales han sido plurales, cuando, por necesidad y racionalidad básica, la respuesta debería haber sido "coordinada, cooperativa y solidaria".

Muchas personas pueden sospechar que los Estados en que habitan y desarrollan su ciudadanía son reales "Estados de bienestar". Francamente, al revisar los resultados de la calamitosa peste, muy pocos Estados en el mundo puedan revestir, en la letra y en la práctica, un real Estado de bienestar para sus ciudadanos y ciudadanas. La mayoría de las Leyes fundamentales del mundo se refieren al derecho a la salud y predican un Estado de bienestar. Pero ha quedado demostrado que en la realidad efectiva ello no se realiza y, por ende, no se concreta el carácter imperativo de las lenguas escritas constituyentes de los Estados.

Además, el virus es un ataque global a la precariedad del sistema de salud. Sin salud no hay existencia humana digna. La pandemia nos obliga a repensar sobre nuevas formas de concepción y cooperativismo para el derecho a la salud, dentro de cada Estado y entre los Estados entre sí a nivel mundial, siempre dentro del contexto propiciado por la democracia para la arquitectura y coexistencia humana en el Estado de Derecho.

Las medidas adoptadas hasta ahora no han logrado contener el virus. Su mitigación se realiza con el "ASPO". Este modelo extremo de distanciamiento entre las personas compromete la economía, la salud emocional, el equilibrio de la sociedad y el desempeño de las instituciones. Apoyar el "ASPO", transitorio en el tiempo y justificado en el espacio del Derecho, como herramienta indispensable para proteger la existencia con vida de las personas de una comunidad y evitar el colapso sanitario también indica que no existe una respuesta correcta para combatir la pandemia. Probablemente, el concierto de la economía, la salud, la comunidad y el Estado permita inducir determinado equilibrio para el levantamiento de este estado de excepción o, acaso, su renovación parcial, como ha venido ocurriendo, no sólo en la Argentina. Porque hasta tanto no se encuentre la vacuna, el mal persistirá. Estuvimos, estamos y estaremos 
en peligro. Mientras tanto, las decisiones gubernamentales, sus políticas públicas, deben adoptarse con un basamento explícito fundado en las ciencias.

Por lo tanto, no debería resultar extraña la discusión de una nueva constelación que, con bases igualitarias, exponga un giro radical y contemple la universalidad del derecho a la salud. Un mínimo básico, fundamental, irrenunciable, riguroso, intocable, que le corresponde universalmente a cada individuo por el hecho de ser humano y que por ser humano goza de esa protección universal individuada en su persona.

Pese a todo, hoy, 15 de abril de 2020 -mientras escribimos estas páginas-, somos cautos. La concepción de la salud como un derecho fundamental, universal, integral y público debería formar parte de una agenda de discusión, en todos los niveles: local, regional y estatal. Para dirigirse con su proa hacia un "programa mundial" solidario, que conquiste y concite en grado sumo la prevención y el cuidado de la salud de toda la humanidad. Para que otra pandemia no nos tome por sorpresa y sin vigilancia. Con responsabilidad hacia las generaciones futuras y la obligación que conlleva no descuidar la arquitectura de nuestro aparato psíquico.

En pocas palabras: que el Estado de bienestar, en toda su dimensión y complejidad, despoje o al menos contenga racionalmente al malestar viral que en el presente provoca dolor y sufrimiento al ser humano. Sin grandilocuencia: hombres y mujeres deberíamos unir fuerzas y luchar juntos hacia adelante, arrancar el malestar y procurar el bienestar. 